\title{
Peertechz
}

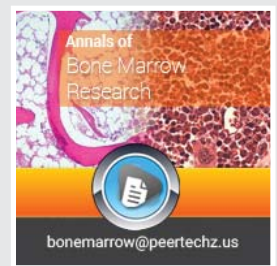

\section{Acute Panmyelosis with Myelofibrosis: The Serpentine Road to Diagnosis}

\author{
Celia Suriu ${ }^{1,2}$, Andrei Braester ${ }^{1,2 *}$ and Masad Barhoum ${ }^{1,2}$ \\ ${ }^{1}$ Galilee Medical Center, Bar-Ilan University, Israel \\ ${ }^{2}$ Azrieli Faculty of Medicine, Bar-Ilan University, Israel
}

Received: 30 March, 2021

Accepted:12 May, 2021

Published: 13 May, 2021

*Corresponding author: Andrei Braester, Galilee Medical Center, Bar-Ilan University, Israel, Tel: 972507887943;

E-mail: andreib@gmc.gov.il, braester@bezeqint.net ORCID: http://orcid.org/0000-0002-1567-7562 https://www.peertechzpublications.com

\section{Check for updates}

Acute Panmyelosis with Myelofibrosis (APMF) is an extremely rare disease. Lack of familiarity with this rare subtype of acute leukemia hinders the diagnosis [1]. It is characterized by an acute, rapidly progressive, fatal clinical course, peripheral blood cytopenias with minimum $20 \%$ blast and no detectable splenomegaly. APMF corresponds to less than $1 \%$ of the cases of Acute Myeloid Leukemia (AML) [2]. Histologically, APMF is characterized by a heavily fibrotic marrow, an increased number of immature hematopoietic elements (panmyelosis), and dysplastic population of megakaryocytes. The condition should be differentiated from other hematological neoplasms that present with fibrosis such as acute megakaryoblastic leukemia and myelodysplsia (MDS) with myelofibrosis. Dacrocytes are not present.

In our department a 78-year-old female was investigated for fever and hypoxemia. On physical examination, she was pale, without palpable lymph nodes or abdominal organomegaly. Her CBC showed macrocytic anemia with a hemoglobin level of 8.4 $\mathrm{g} / \mathrm{dL}$, an MCV of $104 \mathrm{fl}$, leucopenia $(2100 / \mu \mathrm{l})$ with neutropenia $(400 / \mu l)$. The platelet count was $53000 / \mu l$. Dacrocytes were not seen. Serum LDH (3.8 X ULN) and CRP were high. There was normal vitamine B12 and folic acid level.

Flow cytometry of peripheral blood showed $18 \%$ blasts (CD 34+, CD 117+, HLA-DR+, CD33+, CD123+). BCR-ABL1 and JAK2V617F mutations in peripheral blood were negative. A bone marrow aspiration was "dry tap". Biopsy reveals a hypercellular fibrotic bone marrow with panmyelosis and increased precursors in all three lineages with markedly increased number of the megakaryocytes The karyotype was normal.

\section{MPO was negative}

Computerized tomography revealed no lymphadenopathy or organomegaly.
The patient was diagnosed with acute panmyelosis with myelofibrosis based on the clinical course and bone marrow biopsy. The patient died two months from diagnosis due to septic shock.

APMF is listed in the category of "AML, not otherwise specified (NOS)" [3]. There are difficulties concerning the differential diagnosis between APMF, MDS with excess blasts and concomitant fibrosis (MDS-EB-F) and Acute Megakaryoblastic Leukemia (AMKL)[4]. Our patient fulfilled the criteria of APMF: the patient had a typical clinical course, no morphological abnormalities in the peripheral blood, no splenomegaly, and the bone marrow was hypercellular with a diffuse fibrotic stroma with immaturity of all trilineage cells and markedly increased number of abnormal megakaryocytes. In AMKL the number of blasts can be the same as in APMF, but they are predominantly megakaryocytic in nature, and $\mathrm{CD} 34$ is usually negative ${ }^{4}$. In both situations the bone marrow is frequently not aspirable (as in our case).

The distinction from MDS associated with both excess of blasts and myelofibrosis (MDS-EB-F) is particularly difficult, since the morphological findings are similar. However, in APMF the bone marrow shows more numerous megakaryocytes and a higher number of blasts, than are found in MDS-EB-F. An important clinical differences between the two conditions, is the abrupt onset of APMF and its shorter survival rate in comparison with MDS-EB-F [5].

The distinction from Primary Myelofibrosis (PMF) is usually less problematic.

The clinical course in the later condition is more indolent, and splenomegaly of varying degree is detected in up to $90 \%$ of patients and may be massive. The JAK2V617F mutation 
may be found in $50 \%$ of patients. Our patient did not have splenomegaly, and the clinical course was not typical of PMF.

\section{The JAK2 mutation was negative}

The pathogenesis of APMF is unknown, and the rarity of the disease makes its diagnosis a medical challenge. The disease is usually associated with poor response to chemotherapy and a survival period of only several months. A rapid diagnosis and a proper management including chemotherapy and the option of stem cell transplantation, even in elderly patients, seems mandatory for APMF patients.

In our case, the patient was not fit to be treated with chemotherapy, and the clinical evolution was rapidly progressive, with septic shock being the final event.

\section{References}

1. Tracy IG, Ashish B (2021) Diagnosis of rare subtypes of acute myeloid leukemia and related neoplasms. Pathology. Epub ahead of print. Link:
https://bit.ly/3hl9UeX

2. Chatterjee T, Gupta S, Sharma A, Sharma S, Gupta D (2013) Acute panmyelosis with myelofibrosis-a rare subtype of acute myeloid leukemia. Mediterr $J$ hematol Infect Dis 5: e2013042. Link: https://bit.ly/3bDuRhJ

3. Arber DA, Orazi H, Hasserjian R, Thiele J, Borowitzet MJ, et al (2016) The 2016 revision of World Health Organization (WHO) classification of myeloid neoplasms and acute leukemia. Blood 127: 2391-2405. Link: https://bit. ly/3tHLCy6

4. Orazi A, O'Malley DP, Jiang J, Vence GH, Thomas J, et al. (2005) Acute panmyelosis with myelofibrosis: an entity distinct from acute megakaryoblastic leukemia. Mod Pathol 18: 603-614. Link: https://bit.ly/3hlzEbg

5. Bae E, Park CJ, Cho YU, Seo EJ, Ch HS, et al. (2013) Differential diagnosis of myelofibrosis based on WHO 2008 criteria: acute panmyelosis with myelofibrosis, acute megakaryoblastic leukemia with myelofibrosis, primary myelofibrosis and myelodysplastic syndrome with myelofibrosis. Int J Lab Hematol 35: 629-636. Link: https://bit.ly/3w3BJML
Discover a bigger Impact and Visibility of your article publication with

\section{Peertechz Publications}

\section{Highlights}

* Signatory publisher of ORCID

- Signatory Publisher of DORA (San Francisco Declaration on Research Assessment)

* Articles archived in worlds' renowned service providers such as Portico, CNKI, AGRIS, TDNet, Base (Bielefeld University Library), CrossRef, Scilit, J-Gate etc.

* Journals indexed in ICMJE, SHERPA/ROMEO, Google Scholar etc.

* OAI-PMH (Open Archives Initiative Protocol for Metadata Harvesting)

* Dedicated Editorial Board for every journa

* Accurate and rapid peer-review process

* Increased citations of published articles through promotions

* Reduced timeline for article publication

Submit your articles and experience a new surge in publication services (https://www.peertechz.com/submission).

Peertechz journals wishes everlasting success in your every endeavours.

Copyright: @ 2021 Suriu C, et al. This is an open-access article distributed under the terms of the Creative Commons Attribution License, which permits unrestricted use, distribution, and r eproduction in any medium, provided the original author and source are credited. 